\title{
Development of approaches to identification of systemic importance of insurance companies
}

\author{
Tatiana Ignatova ${ }^{1, *}$, Elena Alifanova ${ }^{2}$, Yulia Evlakhova $^{2}$, and Christos Alexanis ${ }^{3}$ \\ ${ }^{1}$ Russian Presidential Academy of National Economy and Public Administration, Moscow, Russia \\ ${ }^{2}$ Rostov State University of Economics, Rostov-on-Don, Russian Federation \\ ${ }^{3}$ ESC Rennes School of Business, Rennes, France
}

\begin{abstract}
The article is devoted to systemically important insurance organizations, problems of their identification, identification of vulnerabilities to financial security threats, risks of money laundering and terrorist financing. The authors proposed a new criterion for the systemic importance of insurance companies (links with systemically important banks), which, together with the existing indicators, can be used in identifying both global and national systemically important insurers. Using the example of the links of Russian insurers through the ownership structure with Russian systemically important credit institutions, the possibilities of applying this criterion were shown: the pairs of links in the Russian market and the types of links between organizations were identified, the selection of insurance companies was carried out. As a result of the study, the authors compiled a list of Russian insurers that can be considered systemically important in the Russian financial market. General vulnerabilities of systemically important insurance and credit organizations were determined based on the analysis of reports on the national assessment of money laundering and terrorist financing risk. The obtained results can be used by state bodies for regulating the financial market and financial monitoring when developing a policy for regulating the insurance sector.
\end{abstract}

\section{Introduction}

The issues of systemic importance of financial organizations that have appeared on the agenda after the 2008 crisis remain relevant, since they affect financial stability of the country and its economic security. To date, the criteria for the systemic importance of financial institutions have been developed in Russia and in the world, methods for their identification have been formed, a special regime for regulating systemically important financial institutions has been developed and is being implemented, nevertheless, there are still questions that require scientific understanding and research.

The unequal size of the contribution to the systemic risk of banks, insurance and investment companies is discussed in [1]. The results of empirical studies showed that in 2004-2012 the investment companies sector contributed more to systemic risk in the

\footnotetext{
*Corresponding author : tignatova1965@gmail.com
} 
Eurozone countries, and the insurance sector - in the USA. However, other studies, in particular [2], substantiated and empirically confirmed on the data of 39 countries the positive role of the insurance sector in the fight against systemic banking crises. The researchers of the Russian financial market have come to similar results [3].

The methodology for identifying systemically important insurance companies at the global level was developed by the International Association of Insurance Supervisors (IAIS) in 2013. In this methodology, the subjective approach (regulator's judgment) is combined with the indicator approach [4]. The companies selected as a result of identification - global systemically important insurers - after recognition of systemic importance changed their behavior in a certain way (as shown in [5] based on the analysis of the default probability and the dynamics of the return on shares of these companies).

In the Russian financial market, systemically important participants are: a) credit institutions (due to dominance in terms of assets); b) separate infrastructural organizations (due to uniqueness of the services provided).

In Russia, in 2012-2015, the Central Bank of the Russian Federation developed criteria for the systemic importance of insurance companies, the main of which was the size of insurance premiums. On their basis, 20 insurers with the highest level of insurance premiums were selected. It also introduced enhanced supervision of compliance with the requirements of insurance legislation by systemically important insurance companies. However, since 2016, the opinion that insurance companies are not systemically important participants in the Russian financial market has emerged and has become firmly established, and therefore the special regulatory regime for systemically important insurers was canceled. However, active development of the Russian bank insurance market, the leaders of which are insurance companies associated with systemically important banks, as well as changes in the prudential regulation of the insurance market, made it necessary to return to the problem of the systemic importance of insurance companies. Let us note scientific articles, which propose original indicators that enable to identify systemically important insurance companies. The work [6] defines the financial ratios responsible for assigning the status of systemically important to an insurance company within the framework of IAIS methodology. A methodology for identifying systemically important insurance companies focused on ensuring national security is proposed in article [7].

Summarizing the state of research on this issue, including approaches to determining systemic importance of insurers, we propose to consider their relationship with systemically important banks as a criterion for identifying systemically important insurance companies. This criterion is especially relevant for national financial markets with a developed sector of bank insurance services, such as the Russian market. With regard to the domestic market, we propose to use the criterion of the relationship of insurance companies with systemically important banks in addition to the indicator 'size of insurance premiums' used by the Central Bank of the Russian Federation.

Analysis of research on the problem of identifying systemically important insurance companies, as well as work on the development of bank insurance, enabled us to systematize the types of relationships between insurance and credit organizations:

a) customer relations: insurance organizations using such banking services as cash and settlement services, placing funds on deposits, etc. and vice versa, credit institutions using insurance services such as property insurance (ATMs, car fleet, real estate), voluntary medical insurance for employees, insurance of bank risks, etc.;

b) intermediary relationship: the bank as an intermediary between the client and the insurance company, including non-credit insurance (insurance of risks of cardholders, insurance of property of individuals, insurance for traveling abroad, investment life insurance, etc.) credit insurance (insurance of the borrower against job loss, life and health insurance of the borrower, car insurance, mortgage insurance, etc.); 
c) relationships within financial groups, financial conglomerates, financial and industrial groups.

Analysis of the relationships of the latter group is of interest, since the links by ownership structure are significant in the formation of a network of critical vulnerabilities of the national financial system to threats to financial security and the risk of money laundering and terrorist financing.

Based on the results of the analysis of relations between insurance and systemically important credit institutions within financial groups, the following were identified:

- insurance companies and systemically important banks linked by property relations;

- systemically important banks that are not associated with ownership relations with insurance companies.

Obviously, the first option indicates a high level of systemic importance of insurance companies, while the second indicates the absence of systemic importance according to the criterion of interconnection with systemically important banks (which does not exclude such importance according to other criteria).

\section{Research methods and materials}

The information base of the study was made up of data on the ownership structure of systemically important banks. Such data are provided by the Bank of Russia and SPARKInterfax (a comprehensive solution for verifying legal entities, private entrepreneurs, directors and shareholders in Russia, Ukraine, Kazakhstan, Belarus, Kyrgyzstan, Uzbekistan and Moldova).

The authors have developed an algorithm for the selection of insurance companies in the Russian Federation according to criteria of systemic importance (insurance premium size, links with systemically important banks by ownership structure), which includes the following stages:

1. selection of insurance companies in the Russian Federation, included as of the current date in the top 20 in terms of insurance premiums. The top 20 was chosen because it covers more than $80 \%$ of all insurance premiums in the Russian market. It should be noted that the size of insurance premiums and market share are, as proved in [8], the main factors influencing efficiency of the functioning of insurance companies;

2.identification of relationships in the ownership structure between a group of 11 systemically important banks and a group of 20 insurance companies;

3.defining the types of relationships by ownership structure between insurance companies and systemically important banks;

4. formation of the final list of insurance companies, which are simultaneously included in the top 20 in terms of assets and have links by ownership structure with systemically important banks, that is, they can be regarded as systemically important.

To select Russian insurance companies in the top 20 in terms of insurance premiums, we used Expert RA ranking (Russia's oldest and largest credit rating agency).

\section{Discussion}

To identify relationships in the ownership structure between a group of 11 systemically important banks and a group of 20 insurance companies, we have built relationships in SPARK-Interfax. As a result, it was determined that there were pairs 'systemically important bank - insurance company' on the Russian financial market, analysis of which by ownership structure enabled us to determine the types of links between systemically 
important banks and the largest insurance companies in terms of insurance premiums in the Russian market:

a) participation of a bank in the capital of an insurance company,

b) participation of an insurance company in the capital of a bank

c) indirect links by ownership structure (through the chain of companies),

d) historical ties,

e) common nominee shareholder of a bank and an insurance company.

Thus, according to SPARK-Interfax, VSK JSIC is linked with Safmar Financial Investments PJSC on the principle of mutual ownership of each other's shares: VSK owns $1.71 \%$ of Safmar Financial Investments and, vise versa, Safmar Financial Investments owns $49 \%$ of VSK shares. In addition, both companies have the same board members. In turn, $7.67 \%$ of shares of Safmar Financial Investments PJSC belong to Trust Bank (PJSC), whose board members are also on the board of directors of Otkritie FC Bank PJSC. Thus, it can be argued that through the chain of companies, VSK JSIC has links in terms of ownership structure with Otkritie FC Bank PJSC.

As for the links in the structure of ownership of the insurance company RESO-Garantia IPJSC, according to SPARK-Interfax, its co-owner is Rossiya Airlines AO, 75\% of which, in turn, belongs to Aeroflot PJSC. Rosimushchestvo owns $51.17 \%$ of shares in Aeroflot PJSC, which also owns stakes in such systemically important banks as Rosselkhozbank JSC (100\%), Promsvyazbank PJSC (100\%), VTB Bank PJSC (77.47\%). Thus, RESO-Garantia IPJSC through a chain of companies is included in the pool of organizations, the main owner of which is a state structure.

To form the final list of systemically important insurance companies, we selected those insurance organizations that have either direct or indirect ties with systemically important banks. As a result, the list of insurance companies in the Russian Federation, which can be regarded as systemically important based on a set of criteria - the size of insurance premiums and links by ownership structure with systemically important banks - is as follows: Societe Generale Life Insurance LLC, Rosgosstrakh Insurance Company LLC, Rosgosstrakh Life Insurance Company LLC, Sberbank Insurance LLC, Sberbank Life Insurance LLC, Ingosstrakh IPJSC, VSK JSIC, RESO-Garantia IPJSC.

Distinguishing from the total number of insurance organizations those companies that are significant in terms of assets and, moreover, are associated with property relations with systemically important banks, means confirmation of their systemic importance for the financial market, which actualizes the issues of identifying their vulnerabilities to the risk of money laundering and terrorist financing (ML/TF).

In the case of systemically important insurance companies, vulnerabilities to ML/TF risk consist of vulnerabilities associated with insurance activities, as well as vulnerabilities inherent in systemically important banks.

Vulnerabilities of insurance companies to ML/TF risk are disclosed in such typological reports of regional groups of the FATF type, such as:

1)Money laundering through private pension funds and the insurance sector. Typology research, MONEYVAL, 2010.

2)Money laundering through insurance companies. EAG, 2018.

In general, these reports indicate that such characteristics of insurance as international nature of its activities, peculiarities of some insurance products, the widespread use of insurance products by individuals and legal entities, increase the risk of its use for ML/TF purposes.

The study of these reports, systematization and generalization of the characteristics of insurance activities that contribute to its exposure to the risk of ML/TF, led us to the following conclusions about vulnerabilities of insurance companies to the risk of ML/TF: 
1)the use of standard practice in the insurance sector to attract intermediaries (involvement of foreign intermediaries increases ML/TF risk to a greater extent);

2)special types of insurance products, in particular: reinsurance contracts concluded with foreign reinsurance brokers; life insurance policies with a cumulative element and a one-time payment of the insurance premium, investment insurance products and life insurance policies;

3)features of the process of implementing an insurance contract, namely: the client's right to early cancellation of the policy (early termination of the insurance contract); the client's right to amend the content of the policy (for example, change of the policy holder, beneficiary, insured person).

With regard to the Russian insurance sector, both the level of threat of its use for ML purposes, and the level of its vulnerability to ML risks, are assessed as moderate (according to the results of the National money laundering risk assessment 2017-2018: key findings). Risks of the involvement of Russian insurance companies in dubious operations to withdraw funds abroad under the guise of reinsurance are noted. Nevertheless, the Rosfinmonitoring activity report 2019 notes that the risk of using insurance entities for legalization purposes remains relevant, and implementation of scheme operations/transactions/actions in the interests of owners, which are aimed at the withdrawal of assets and collected insurance premiums' continues.

Attraction, movement and use of funds for financing terrorism through insurance organizations is the least popular way, as it requires additional actions on the part of terrorists.

Comparison of vulnerabilities of insurance companies, stated in the typological reports of MONEYVAL and EAG, with the Russian practice of using insurance companies for legalization purposes, leads us to the following conclusion. Regional groups like FATF, as a result of generalization of situations in different countries, prioritize vulnerabilities associated with the risks of customers, counterparties, as well as products of insurance companies. However, Russian practice shows that the key vulnerability of insurance companies is risks associated with illegal interests of the owners.

As for the vulnerabilities of systemically important banks to the ML/TF risk, they were identified and disclosed by us in [9].

\section{Results}

Generalization of vulnerabilities in the activities of credit and insurance organizations, including systemically important ones, makes it possible to determine the general vulnerabilities to ML/TF risk, to which both systemically important banks and related insurance companies are exposed:

- interconnection of country risk with the risk of money laundering, which is realized in banks through correspondent relations with foreign banks and operations under foreign trade contracts, and in insurance companies through the involvement of foreign intermediaries and reinsurance agreements concluded with foreign brokers. This zone of vulnerability is also confirmed by the results of other studies, in particular, in [10], patterns of relationships between the level of country risks, the elasticity of income of insurance companies and the participation of banks in insurance activities are determined.

- relationship between reputational risk and the risk of money laundering, which both in banks and insurance companies are realized through the actions of customers, counterparties and employees, which form business reputation of a financial institution. The growing importance of reputation risk in the management of credit and insurance organizations was revealed in [11] based on data from European and American companies. 
- use of remote service systems, due to which both banks and insurance companies are exposed to cyberattacks and damage to information infrastructure.

- persistence of the risks of using cash for illegal purposes, which are relevant in banks as a result of the excessive increase in the population's debt burden observed in recent years, and in insurance companies are relevant due to the possibility to receive large amounts of cash; to accept large amounts as a one-time payment for a product; as well as due to a client's right to make changes to the content of the policy (for example, change of the policy holder, beneficiary, insured person).

The reported study was funded by RFBR according to the research project No. 18-010-00657.

\section{References}

1. Bernal O., Gnabo J.-Y., Guilmin G. Assessing the contribution of banks, insurance and other financial services to systemic risk. Journal of Banking \& Finance, vol. 47, pp. 270-287, October 2014. https://doi.org/10.1016/j.jbankfin.2014.05.030

2. Chien-Chiang Lee,Yi-Bin Chiu, Chi-Hung Chang. Insurance demand and country risks: A nonlinear panel data analysis. Journal of International Money and Finance, vol. 36, pp. 68-85, September 2013. https://doi.org/10.1016/j.jimonfin.2013.03.009

3. Nikul'shin D. Insurance institution and the stability of financial market. Voprosy Ekonomiki, no. 11, pp. 143-147, November 2010. [In Russ.] https://doi.org/10.32609/0042-8736-2010-11-143-147

4. Evlakhova Yu.S. Determination of global system-important financial institutions in the insurance and securities sectors of the financial market. Financial Journal, vol. 5, no. 27, pp. 113-119, September-October 2015. [In Russ.]

5. Dewenter K. L., Riddick L. A. What's the value of a TBTF guaranty? Evidence from the G-SII designation for insurance companies. Journal of Banking \& Finance, vol. 91, pp. 70-85, June 2018. https://doi.org/10.1016/j.jbankfin.2018.03.005

6. Penikas G.I., Petrov V.S. The identification of the financial coefficients interrelated with the indicator of systemic importance of insurance companies. Banking, no. 7, pp. 28-33, July 2014. [In Russ.]

7. Nasyrova G. A. Regulation of insurance companies by the prudential approach, Strategic decisions and risk management, no. 4, pp. 60-68, 2015. [In Russ.] https://doi.org/10.17747/2078-8886-2015-4

8. Fenn P., Vencappa D., Diacon S., Klumpes P., O'Briena C. Market structure and the efficiency of European insurance companies: A stochastic frontier analysis. Journal of Banking \& Finance, vol. 32, iss.1, pp. 86-100, January 2008. https://doi.org/10.1016/j.jbankfin.2007.09.005

9. Evlakhova Yu.S., Alifanova E.N. Systemically important financial institutions as an area of vulnerability to threats to financial safety of Russia. Finance and credit, vol. 25, iss. 8, pp. 1712-1726, August 2019. [In Russ.] https://doi.org/10.24891/fc. 25.8 .1712

10. Chien-Chiang Lee, Chun-Wei Lin, Jhih-Hong Zeng. Financial liberalization, insurance market, and the likelihood of financial crises. Journal of International Money and Finance, vol. 62, pp. 25-51, April 2016. https://doi.org/10.1016/j.jimonfin.2015.12.002

11. Heidinger D., Gatzert N. Awareness, determinants and value of reputation risk management: Empirical evidence from the banking and insurance industry. Journal of Banking \& Finance, vol. 91, pp. 106-118, June 2018. https://doi.org/10.1016/j.jbankfin.2018.04.004 